\title{
Performance of Wheat Varieties under Different Date of Sowing in Southern Bihar
}

\author{
Koushik Sar*, Md Riton Chowdhury and Subhaprada Dash
}

Department of Agronomy, Faculty of Agricultural Sciences (IAS), Siksha 'O' Anusandhan

(Deemed to be University), Bhubaneswar-751029, Odisha, India

*Corresponding author

\section{A B S T R A C T}

\section{Keywords}

Wheat, Grain yield, Nitrogen content, Nitrogen removal, Rainfall and Sunshine hours

\section{Article Info}

Accepted: 15 April 2020 Available Online: 10 May 2020
A field experiment during the year 2015-16 and 2016-17 on two sowing dates (November 23, December 15) and three varieties (cv. HD2733, GW322 and K307) with four replications was conducted at the wheat section, Research Farm, Bihar Agricultural University, Sabour, Bhagalpur to study the performance of rice varieties under different date of sowing . Layer wise soil data was generated and climate data was collected from meteorological observatory, Sabour. Crop management and experimental data was measured from the experimental field. Results revealed that irrespective of variety, timely sown wheat (D1) registered significantly higher grain yield over the two years of study than the wheat crop sown under late conditions (D2). The pooled yield over two years also followed a similar trend. Crop sown on DI recorded a grain yield increase of 15.91 per cent over crop yield sown at D2. The interaction effect between date of sowing and varieties was found to be significant. The treatment combination (D1V1) recorded significantly highest grain yield (47.5 and $48.3 \mathrm{q} \mathrm{ha}^{-1}$ ) over rest of the treatment combinations and next in order was D1V2 treatment combination with grain yield of 43.7 and $44.4 \mathrm{q} \mathrm{ha}^{-1}$ during both the years of experimentation and pooled of the years. The lowest yield reduction of $13.35 \%$ was recorded in $\mathrm{V} 1$ while the maximum yield reduction of $17.30 \%$ was recorded in $\mathrm{V} 3$ for $\mathrm{D} 2$ sowing.

\section{Introduction}

Wheat ranks first among the world food crops, in terms of cultivated area (223.813 million ha), production (733.144 million tonnes) and with productivity of (3280 kg ha1) (USDA 2016). It can be grown from below sea level to $5000 \mathrm{~m}$ altitude and in areas where rainfall ranges between $300-1130 \mathrm{~mm}$.
Wheat contributes more calories (20\%) and more protein to the world's diet than any other food crop and is staple food in at least 43 countries The availability of wheat has increased from about 79 gm capita- 1 day-1 to more than 185 gm capita-1 day-1 despite the doubling of the population since 1961 (Bhardwaj et al., 2010). Production trends of wheat in India during last five decades have 
clearly shown a very rapid rate of increase in area, production and productivity, which could be attributed to the advent of fertilizer responsive dwarf and semi-dwarf high yielding varieties in mid-sixties and matching production technology. In India, wheat is the second most important cereal crop next only to rice and a key crop of the green revolution and post green revolution era. India stands second among wheat producing countries after China. During the crop year 2013-14, wheat was grown over an area of 31.18 million ha with the production of 95.91 million tonnes with an average productivity of 3.07 tonnes ha-1 (DAC 2014-15). On the other hand, due to increasing population pressure, the demand for wheat along with other cereals and food crops is rapidly increasing. As per present population growth rate, the population of India is expected to be around 1.3 billion by 2025 AD. Assuming $20 \%$ more per capita requirement of food grains, due to better standard of living and increase in the demand of processing industries, required wheat production will be around 109 million tonnes by 2025 AD (DWR, 2013) against the limitation of expansion of the cultivable land area. The only alternative to achieve this goal is to raise its productivity level through improved varieties and the matching production technology. Bihar is potentially an important wheat growing state, but it contributes only $5.8 \%$ towards national production from an area of 2.25 million ha with a productivity of 2.25 tons/ha (DES, 2013-2014). This clearly indicates that in spite of considerable improvement in genetic potential of the crop; productivity of wheat is very poor in the states than Punjab (4307 kg ha-1) and Haryana (4213 kg ha-1), in light of realized yield level of 45- $50 \mathrm{q}$ ha-1. Keeping this in view, a field experiment was carried out to study the performance of Wheat varieties under different date of sowing.

\section{Materials and Methods}

Field experiment was carried out during 2015-16 and 2016-17 in Rabi season at area specified to wheat section at Research Farm, Bihar Agricultural University, Sabour, Bhagalpur, Bihar, India with two different date of sowing viz-D1 (Timely Sown): 23rd November, D2 (Late Sown) : 15th December, and three different varieties viz-V1: GW322 V2: HD2733 V3: K307. The experiment was laid out in Split Plot Design, with four replication. The crop was harvested at maturity from an area of $5.0 \mathrm{~m} 2$ earmarked for yield estimation of each plot. Small bundles were made, after drying the harvested plants for couple of days in the field. The sun dried bundles of wheat were threshed plot wise using power operated thresher. The dried grain weights were recorded plot wise and converted into $\mathrm{kg}$ ha-1 at $12 \%$ moisture content. The nitrogen, content in grain, stems and tops of wheat were estimated after harvest. The plant samples (grain and stem) were collected plots wise at harvest. These samples were ground in the Willey's mill after drying in oven at $60+5{ }^{0} \mathrm{c}$ temperature for 48 hours. The ground plant material was then passed through a 30 mesh sieve and used for determination of $\mathrm{N}$. The nutrient content of these materials were analyzed chemically in laboratory by Macrokjeldahl method (Nicholas and Nelson, 1957).

\section{Results and Discussion}

\section{Weather conditions during crop seasons Rabi 2016 and 2017}

The daily weather data of both the crop growth seasons were collected from the Agrometeorological Observatory, Sabour. The average of seven days (SMW) was worked out for temperatures, sunshine hours, total rainfall for graphical presentation. The average values are presented in Table 1 


\section{Rainfall}

The total crop growth period rainfall was only $53.4 \mathrm{~mm}$ and its distribution was not good throughout the crop season in all the dates of sowing during 2015, whereas only $27.9 \mathrm{~mm}$ rainfall was recorded by the year 2016 and distribution of rainfall was very erratic throughout the crop season under the two dates of sowing. The total amount of rainfall was quite low in all the dates of transplanting in the during both years of study. Crop received maximum rain of amount 24.4 and $23.2 \mathrm{~mm}$ during 3rd and 14th SMW (period coinciding with vegetative and maturity stage) in 2015, whereas corresponding values were lower of 12.4 and $5.9 \mathrm{~mm}$ during 4th and 12th SMW (period coinciding with vegetative and post anthesis stage) in during the crop season of 2016 .

\section{Sunshine hours}

The values of the bright sunshine hours exhibited more fluctuations during the both years of study period. The average value of daily bright sunshine hours were 3.7 and 4.6 hours for 2015 and 2016 crop seasons respectively with good variation from one date of sowing to another (Table 1). Maximum values of average sunshine hours $(8.0 \mathrm{hrs})$ were recorded during the anthesis and maturity stage during 2007, whereas, corresponding average values of sunshine were maximum ( $7.4 \mathrm{hrs}$ ) during pre-flowering and maturity stage in the year 2016. The deviation of actual value from the mean was more pronounced in the beginning stages of crop growth during both the years.

\section{Effect on grain yield of wheat crop}

The experimental results of grain yield of various cultivars of wheat as influenced by different dates of sowing are presented in
Table 2. The timely sown wheat (D1) registered significantly higher grain yield over the two years of study than the wheat crop sown under late conditions (D2). The pooled yield over two years also followed a similar trend. Crop sown on D1 recorded a grain yield increase of 15.91 per cent over crop yield sown at D2. As regards the effect of different cultivar, the results revealed that V1 has significantly recorded the highest grain yield over V2 and V3 during both years of study. The pooled data over two years also followed a similar trend. However, V2 and V3 although recorded lower yield values during the two years of study and over pooled did also differ significantly in this regard. V1 recorded a grain yield increase of 11.35 and 14.25 per cent over V2 and V3. Grain yield decreased significantly as sowing was delayed from 23 November to mid December. This might be due to cumulative effect of poor expression of vegetative growth and yield contributing characters i.e. number of ear heads, ear length, ear weight and test weight under late sown conditions accompanied with high temperature and hot winds which leads toward forced maturity of the crop and ultimately resulted in lower grain yield. The early sown crop, on the other hand, having favorable cool weather conditions for longer duration recorded better growth and yield attributes resulted in greater productivity. Similar results have also been reported by Dhaka et al., (2006) and Shirpurkar et al., (2007).

\section{Interaction effect between dates of sowing and different cultivars of wheat}

The interaction between date of sowing and variety was found to be significant. The grain yield of all the varieties was significantly lower when sown under late conditions (D2) compared to timely sown (D1) during the two years of study and over pooled. 
Table.1 Average values of various weather elements (Max. Temp., Min. Temp., Mean temp. and total rainfall occurred during crop growing period under various dates of sowing in Rabi 2015 and 2016

\begin{tabular}{|c|c|c|c|c|}
\hline \multirow[t]{2}{*}{ Date of sowing } & \multicolumn{4}{|c|}{ Weather elements } \\
\hline & Max. Temp. ${ }^{\circ} \mathrm{C}$ & Min. Temp. ${ }^{\circ} \mathrm{C}$ & BSSH (Hrs) & Total Rainfall \\
\hline \multicolumn{5}{|c|}{ Crop season 2015} \\
\hline D1 (23 November) & 27.50 & 12.15 & 3.70 & 53.4 \\
\hline D2 (15 December) & 28.08 & 12.05 & 4.10 & - \\
\hline $\begin{array}{l}\text { Crop season } \\
\text { (Average) }\end{array}$ & 27.79 & 12.10 & 3.90 & 53.4 \\
\hline \multicolumn{5}{|c|}{ Crop season 2016} \\
\hline D1 (23 November) & 26.48 & 11.75 & 4.55 & 22.1 \\
\hline D2 (15 December) & 26.78 & 12.25 & 4.81 & 27.1 \\
\hline $\begin{array}{l}\text { Crop season } \\
\text { (Average) }\end{array}$ & 26.63 & 12.0 & 4.68 & 24.6 \\
\hline
\end{tabular}

Table.2 Effect of dates of sowing on grain yields $\left(\mathrm{q} \mathrm{ha}^{-1}\right)$ of various cultivars of Wheat

\begin{tabular}{|l|c|c|c|}
\hline Treatment & $\mathbf{2 0 1 5}$ & $\mathbf{2 0 1 6}$ & Pooled \\
\hline Main Plots & & & \\
\hline D1 (23 November) & 44.3 & 45.1 & 44.6 \\
\hline D2 (15 December) & 37.2 & 37.8 & 37.5 \\
\hline SEm \pm & 0.32 & 0.22 & 0.12 \\
\hline CD (p=0.05) & 1.44 & 0.98 & \\
\hline Sub Plots & & & 44.9 \\
\hline V1 (HD2733) & 44.5 & 45.2 & 39.8 \\
\hline V2 (GW322) & 39.9 & 40.4 & 38.5 \\
\hline V3 (K307) & 37.9 & 38.7 & 0.15 \\
\hline SEm \pm & 0.42 & 0.26 & 0.47 \\
\hline CD $(\mathbf{p}=\mathbf{0 . 0 5})$ & 1.28 & 0.81 & 48.08 \\
\hline Interaction (DXV) & & & 41.66 \\
\hline D1V1 & 47.5 & 48.3 & 43.59 \\
\hline D2V1 & 41.4 & 42.1 & 35.93 \\
\hline D1V2 & 43.7 & 44.4 & 42.18 \\
\hline D2V2 & 36.0 & 36.4 & 34.88 \\
\hline D1V3 & 41.7 & 42.6 & 0.21 \\
\hline D2V3 & 34.1 & 34.9 & 0.66 \\
\hline SEm \pm & 0.59 & 0.37 & 1.15 \\
\hline CD (p=0.05) & 1.82 & & \\
\hline
\end{tabular}


Table.3 Grain and stem nitrogen content (\%) as influenced by dates of sowing and different cultivars of wheat

\begin{tabular}{|c|c|c|c|c|}
\hline \multirow[t]{2}{*}{ Treatment } & \multicolumn{2}{|c|}{ Grain N Content } & \multicolumn{2}{|c|}{ Stem N Content } \\
\hline & 2015 & 2016 & 2015 & 2016 \\
\hline \multicolumn{5}{|l|}{ Main Plots } \\
\hline D1 (23 November) & 1.60 & 1.61 & 0.58 & 0.59 \\
\hline D2 (15 December) & 1.65 & 1.66 & 0.65 & 0.66 \\
\hline SEm \pm & 0.013 & 0.004 & 0.009 & 0.008 \\
\hline $\mathrm{CD}(\mathrm{p}=0.05)$ & 0.060 & 0.018 & 0.038 & 0.037 \\
\hline \multicolumn{5}{|l|}{ Sub Plots } \\
\hline V1 (HD2733) & 1.66 & 1.66 & 0.64 & 0.64 \\
\hline V2 (GW322) & 1.63 & 1.64 & 0.62 & 0.62 \\
\hline V3 (K307) & 1.60 & 1.61 & 0.59 & 0.61 \\
\hline SEm \pm & 0.003 & 0.003 & 0.003 & 0.002 \\
\hline $\mathrm{CD}(\mathrm{p}=0.05)$ & 0.010 & 0.008 & 0.008 & 0.006 \\
\hline \multicolumn{5}{|l|}{ Interaction (DXV) } \\
\hline D1V1 & 1.64 & 1.64 & 0.60 & 0.60 \\
\hline D2V1 & 1.68 & 1.68 & 0.68 & 0.69 \\
\hline D1V2 & 1.60 & 1.61 & 0.58 & 0.59 \\
\hline D2V2 & 1.65 & 1.66 & 0.65 & 0.66 \\
\hline D1V3 & 1.57 & 1.59 & 0.55 & 0.57 \\
\hline D2V3 & 1.64 & 1.63 & 0.63 & 0.64 \\
\hline SEm \pm & 0.005 & 0.004 & 0.004 & 0.003 \\
\hline $\mathrm{CD}(\mathrm{p}=0.05)$ & 0.015 & 0.012 & 0.011 & 0.009 \\
\hline
\end{tabular}


Table.4 Grain and stem nitrogen removal $\left(\mathrm{kg} \mathrm{ha}^{-1}\right)$ as influenced by dates of sowing and different cultivars of wheat

\begin{tabular}{|l|l|l|l|l|}
\hline \multirow{2}{*}{ Treatment } & \multicolumn{3}{|c|}{ Grain N removal } & \multicolumn{3}{c|}{ Stem N removal } \\
\cline { 2 - 6 } & $\mathbf{2 0 1 5}$ & $\mathbf{2 0 1 6}$ & $\mathbf{2 0 1 5}$ & $\mathbf{2 0 1 6}$ \\
\hline Main Plots & & & & \\
\hline D1 (23 November) & 71.1 & 72.3 & 35.5 & 36.4 \\
\hline D2 (15 December) & 61.5 & 62.6 & 32.3 & 33.0 \\
\hline SEm \pm & 0.82 & 0.76 & 0.32 & 0.33 \\
\hline CD (p=0.05) & 3.70 & 3.44 & 1.45 & 1.50 \\
\hline Sub Plots & & & & \\
\hline V1(HD2733) & 73.5 & 74.8 & 35.5 & 36.2 \\
\hline V2 (GW322) & 64.7 & 65.5 & 34.0 & 34.6 \\
\hline V3 (K307) & 60.6 & 62.0 & 32.2 & 33.2 \\
\hline SEm \pm & 0.65 & 0.40 & 0.14 & 0.18 \\
\hline CD $(\mathbf{p}=\mathbf{0 . 0 5 )}$ & 2.01 & 1.23 & 0.45 & 0.54 \\
\hline Interaction (DXV) & & & & \\
\hline D1V1 & 77.8 & 79.1 & 37.3 & 38.3 \\
\hline D2V1 & 69.3 & 70.5 & 33.7 & 34.2 \\
\hline D1V2 & 69.9 & 71.0 & 35.8 & 36.3 \\
\hline D2V2 & 59.5 & 60.1 & 32.2 & 33.0 \\
\hline D1V3 & 65.5 & 66.8 & 33.5 & 34.8 \\
\hline D2V3 & 55.7 & 57.1 & 30.9 & 31.7 \\
\hline SEm \pm & 0.92 & 0.56 & 0.20 & 0.25 \\
\hline CD (p=0.05) & 2.85 & 1.73 & 0.63 & 0.76 \\
\hline & & & & \\
\hline
\end{tabular}


Figure.1 Normals of maximum and minimum temperature and actual temperature (max., min) and sunshine hrs prevailing during the cropping season of Rabi 2015 and 2016
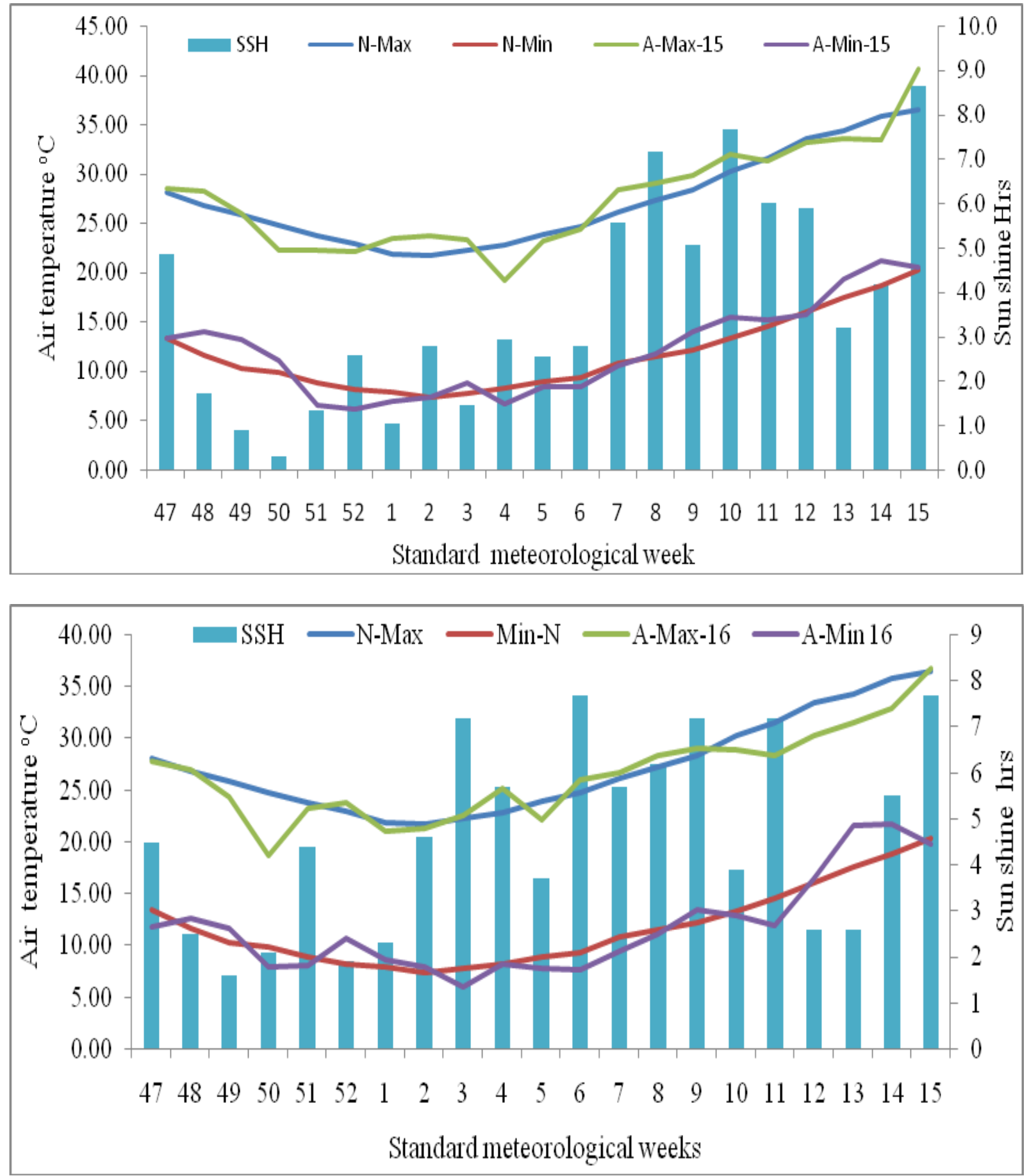
Fig.2 Mean weekly meteorological data during crop growth period of rabi 2015-16 and 2016-17
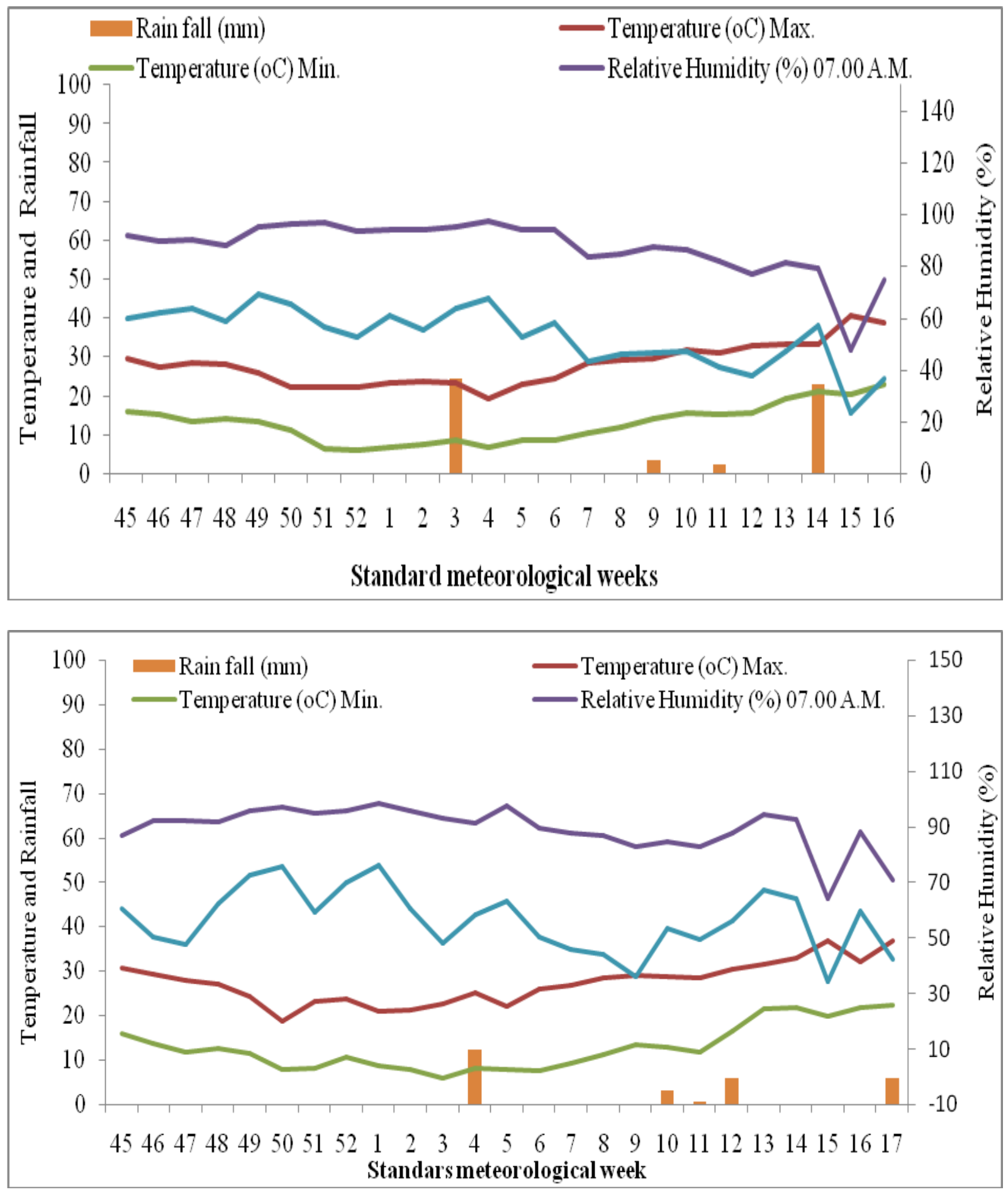

The treatment combination (D1V1) recorded significantly highest grain yield (47.5 and $48.3 \mathrm{q} \mathrm{ha}^{-1}$ ) over rest of the treatment combinations and next in order was D1V2 treatment combination with grain yield of 43.7 and $44.4 \mathrm{q} \mathrm{ha}^{-1}$ during both the years of experimentations and average of the years. 
The lowest yield reduction of $13.35 \%$ was recorded in V1 while the maximum yield reduction of $17.30 \%$ was recorded in V3 for D2 sowing. With delayed sowing of varieties from mid November to mid December, the grain yield gets reduced significantly irrespective of any variety.

\section{Nitrogen content in grain and stem}

It is revealed from the data (Table 3 ) that the maximum $\mathrm{N}$ content in grain and straw was recorded in crop sown under late conditions (D2) during both years of study, indicating magnitude of $\mathrm{N}$ content increases with the increase in sowing dates.

Variety was significantly influenced in terms of Nitrogen (N) content in grain and straw. HD2733 recorded higher $\mathrm{N}$ content in grain and straw as compared to the variety GW322 and K307 during both years of study period. Interaction effect between in terms $\mathrm{N}$ content in grain and straw between variety and sowing dates was found to be significant. Irrespective of variety, a perusal of data revealed that there was significant increase in $\mathrm{N}$ content with increase in date of sowing from November 23 to December 15 during the two years of study. Significantly higher N content in grain (1.64\%) and straw (0.68) was recorded in treatment combination D2V1 followed by the treatment combination D2V2 and D2V3.

\section{Nitrogen removal in grain and straw}

The statistical analysis of data (Table 4) during the two year study revealed that higher $\mathrm{N}$ removal by grain and straw was recorded in timely sown crop (D1), indicating that magnitude of increase in $\mathrm{N}$ removal was significantly increased with the early or timely sowing and decreased with delay sowing. Varieties under study exhibited significant variation in terms of $\mathrm{N}$ removal by the grain and straw during both years of study. The nutrient removal was significantly higher in cv. HD2733 as compared to cv. GW322 and K307. Interaction effect between in terms $\mathrm{N}$ removal in grain and straw between variety and sowing dates was found to be significant. Irrespective of variety, a perusal of data revealed that there was significant reduction in $\mathrm{N}$ removal in grain and straw with increase in date of sowing from November 23 to December 15 during the two years of study. Significantly higher N removal in grain $(78.5 \mathrm{~kg}$ ha-1) and straw (37.8 $\mathrm{kg}$ ha-1) was recorded in treatment combination D1V1 followed by the treatment combination D1V2 and D1V3.

In conclusion, growth and yield potential of crop or variety are the outcome of genomic, environment and agronomic interactions. Since, all the varieties were grown under identical agronomic environment, the observed variation in overall growth of the varieties could be ascribed to their internal genetical make up and external environmental factors to which these were exposed during their life cycle. The grain yield is the sum total of different yield contributing factors controlled both genetically and environmentally. Since, wheat yield formation is a complex process and interaction governed by complimentary interaction between source (photosynthesis and availability of assimilates) and sink component (storage organs). In this experiment, the grain yield was significantly influenced by different varieties and all varieties were noticed significant difference to each other. The highest grain yield (pooled over years) was produced by "HD2733 (44.9 q ha-1) followed by "GW322" (39.8 q ha-1), and "K307" (38.5 q ha-1). The wheat cultivar "HD2733" sown on 23 November, (DIVI) took a longer duration for attaining different phenophases and recorded the maximum yield over two years and pooled. 


\section{References}

Bhardwaj, V., Yadav, V., and Chauhaii, B.S. (2010). Effect of nitrogen application timings and varieties on growth and yield of wheat grown on raised beds, Archives of Agronomy and Soil Science, 56(2), 211-222

DAC, 2014-2015. Department of Agriculture and Cooperation, GOI. Agricultural Statistics at a Glance-2014-2015. Available at: http://eands.dacnet.nic.in/At_A_Glance _2015/4. 7 (a). xls

Dhaka, A.K., Bangarwa, A.S., Pannu, R.K., Malik, R.K. and Garg, R.( 2006). Phenological development, yield and yield attributes of different wheat genotypes as influenced by sowing time and irrigation levels. Agricultural Science Digest, 26(3), 174-177.

Directorate of Statistics and Evaluation. (2015). Planning and Development Department, Government of Bihar Mahdi, S.S. and Haqu, M. (2018). Calibration and Validation of CERES Wheat (DSSAT v4.6) Model for Wheat under Irrigated Conditions: Model Evaluation and Application, Indian Journal of Ecology 45(3): 555-559

Shirpurkar, G.N., Kashid, N.V. and Pisal, A.A. (2007). Effect of different sowing dates and varieties on yield and yield attributes of wheat. Agricultural Science Digest, 27(1), 68-70.

Singh, S., Mukherjee, J., Kumar, S. and Idris, M. (2013). Effect of elevated CO2 on growth and yield of rice crop in open top chamber in sub humid climate of eastern India. Journal of Agrometeorology, 15(1):1-10.

USDA. 2016. United States department of Agriculture, 2016.

White, J.W., Corbett, J.D. and Dobermann, A.(2002). Insufficient geographic characterization and analysis in the planning, execution and dissemination of agronomic research. Field Crops Research, 76(1):45-54.

\section{How to cite this article:}

Koushik Sar, Md Riton Chowdhury and Subhaprada Dash. 2020. Performance of Wheat Varieties under Different Date of Sowing in Southern Bihar. Int.J.Curr.Microbiol.App.Sci. 9(05): 1701-1710. doi: https://doi.org/10.20546/ijcmas.2020.905.191 